ORIGINAL ARTICLE

\title{
Effect of Glycosylated Hemoglobin with Microalbuminuria and Albumin Creatinine Ratio in Type 2 Diabetes
}

\author{
VITASARI INDRIANI ${ }^{1}$, WAHYU SISWANDARI ${ }^{1,2}$, ANDREAS $^{2}$, TRI LESTARI $^{1}$ \\ ${ }^{1}$ Department of Clinical Pathology Department, Medical Faculty, Jenderal Soedirman University \\ ${ }^{2}$ Department of Internal Medicine Department, Prof Dr. Margono Soekarjo Hospital, Purwokerto \\ ${ }^{3}$ Department of Bioethic and Humaniora Department, Medical Faculty, Jenderal Soedirman University. \\ Corresponding author: Vitasari Indriani, Email: vita.indriani@gmail.com, Telp: +6281226717938
}

\begin{abstract}
Background: Diabetes mellitus has strong correlation with end stage renal disease (ESRD) and responsible for $30-40 \%$ of all ESRD cases. This study is focused on assessing the diabetic nephropathy status in patients with type 2 diabetes. Glycated hemoglobin levels over therapeutic targets (>7\%) had two times the risk of complications for diabetic nephropathy, ISN recommends the use of microalbuminuria and urinary albumin creatinine ratio (UACR) for early detection of diabetic nephropathy and for monitoring therapy.

Objective: This study was conducted to prove the correlation between Glycated Albumin with microalbuminuria and UACR in type 2 diabetes.

Methods: Cross sectional study was done in70diabetic type 2 patients who attended PROLANIS program in Primary Health Care from May to November 2018.Detailed medical history including the diabetes duration and relevant clinical examination like FBS, PPBS, $\mathrm{HbA1c}$, urinary creatinineand urinary microalbumin were recorded in each patient.Significance is assessed at $5 \%$ level of significance.

Results: This study obtained the mean age of the study population was $51.89 \pm 6.78$ years with female preponderance (51.1\%).Mean FBS, PPBS, HbA1c, duration of diabetes, blood pressure, microalbuminuria and urinary creatinine were $182.51 \pm 74.63 \mathrm{mg} / \mathrm{dL}, 186.25 \pm 26.72 \mathrm{mg} / \mathrm{dL}, 8.8 \pm 1.83 \%, 9.37 \pm 5.96$ years, $138.44 \pm 14$, $13 / 84.44 \pm 19.25 \mathrm{mmHg}, 30.32 \pm 3.2 \mathrm{mg} / \mathrm{day}$ and $1.33 \pm 0.64 \mathrm{mg} / \mathrm{dl}$ respectively.Microalbuminuria $(r=0.91, p \leq 0.05)$ and UACR $(r=0.67, p \leq 0.05)$ were positively associated with glycated hemoglobin.

Conclusion: It can be concluded that microalbuminuria level and ACR increase in line with the worsening of glycosylated hemoglobin and diabetes duration.

Keywords: Albumin Creatinine Ratio; Diabetes; HbA1c; Microalbuminuria
\end{abstract}

\section{INTRODUCTION}

Diabetic complication, in this case nephropathy, is the leading cause of chronic kidney disease (CKD) and dialysis. ${ }^{1,2}$ The prevalence of diabetic nephropathy is liable for the great issues on the healthcare systems worldwide. Medical costs have increased along with the progression of diabetic nephropathy. ${ }^{3,4}$ In Indonesia for instance, based to the most recent nationwide investigation ${ }^{5}$, the prevalence of diabetic nephropathy and diabetes-related dialysis is increasing. Based on the fact above, one important indicator of renal impairment is the presence of albuminuria $^{6}$. Microalbuminuria is measured by urine albumin excretion rate (UAER) of $20-200 \mathrm{mg} / \mathrm{min}$ or urine albumin to creatinine ratio (UACR) of $30-300 \mathrm{mg} / \mathrm{g}$. It has been considered as initial stage of diabetic nephropathy and the predecessor of undisguised diabetic nephropathy., ${ }^{7,8}$ Therefore, the early detection of microalbuminuria risks can help in preventing or delaying diabetic nephropathy. In line with the previous studies that revealed various factors such as baseline albuminuria, ${ }^{7-9}$ glucose level, glucose variability ${ }^{10,11}$ and insulin resistance ${ }^{12}$ can be used for assessing microalbuminuria risks, this study found that baseline high-normal UACR and glycohemoglobin $(\mathrm{HbA} 1 \mathrm{c})$ levels were the two independent factors that influence microalbuminuria development. Moreover, further associations between these two factors were investigated in our study.

\section{METHODS}

This cross-sectional observational study executed in 70 type 2 diabetes patients who attended PROLANIS program in Primary Health Care from May to November 2018. Patients were checked for their medical history.

Subjects: The sample in this study was 70 people with type 2 diabetic who attended PROLANIS program in Primary Health Care from May to November 2018.

Treatments: It was done by investigating patient's medical history including the diabetes duration and relevant clinical examination such as fasting blood sugar,post prandial blood sugar, $\mathrm{HbA} 1 \mathrm{c}$, urinary creatinineand urinary.

Data Collection and Analysis: This study was enlisted a sample population of 70 type 2 diabetes mellitus (T2D) subjects who attended PROLANIS program in Primary Health Care from May to November 2018. All subjects were periodically monitored for their serum glucose levels, $\mathrm{HbA} 1 \mathrm{c}$ levels, lipid profiles, and creatinine levels four times a year. Furthermore, the patients' UACR and indirect eye fundus were also tested once a year. The subjects enlisted in this study were chosen based on two consecutive UACRs of $60 \mathrm{~mL} / \mathrm{min}$ which monitored during MayNovember 2018. Patients with comorbidities like severe lung, heart, and liver diseases or cancer comorbidities were eliminated from this study. In this study, the term microalbuminuria patients are used for subjects who had a UACR of $>30 \mathrm{mg} / \mathrm{g}$ in two consecutive urine tests. All treatments, including the glycemic, blood pressure, and lipid control treatments for the subjects were executed based on the American Diabetes Association (ADA) guidelines. ${ }^{3}$ Most of the subjects with hypertension in this study were treated with angiotensin-converting enzyme inhibitors (ACEIs) or angiotensin II receptor blockers 
(ARBs). The demographic data such as blood pressure, body mass index, medications for hyperglycemia and hypertension, and retinopathy at the time of measurement were analysed on each patient's medical records. The Mann-Whitney U-test and Pearson's chi-squared test statistical analysis were applied to examine the continuous and categorical variables. In order to find further relationship between the covariates of interest and microalbuminuria, binary logistic regression was applied. In order to determine the cutoff point and assessed the predictive performance for the significant risk factors found in the binary logistic regression, this study used receiver operating characteristic (ROC) curve. Furthermore, Cox regression hazard model was used in this study to delve into the association between independent risk factors and the development of microalbuminuria. Covariates that were related to the development of microalbuminuria or that were considered relative to the microalbuminuria development were regulated. A two-sided $p$ values of $<0.05$ were considered statistically significant. All calculations were executed using Statistical Package for the Social Sciences (SPSS) version 19.0 software (IBM Corp., Armonk, NY).

Ethical Clearance: Ethical approval for this study was attained from the Research Ethics Commitee Medical Faculty Jenderal Soedirman University (the ethical clearance number is 1792/KEPK/IV/2018).

\section{RESULTS}

The initial data of clinical characteristics taken from 70 subjects (consisting of 34 men and 36 women) are presented in Table 1 with subjects' age mean 51.89 \pm 6.78 years. The fasting blood sugar (FBS), post prandial blood sugar (PPBS), HbA1c, duration of diabetes, blood pressure, microalbuminuria and urinary creatinine was $182.51 \pm 74.63 \mathrm{mg} / \mathrm{dL}, 186.25 \pm 26.72 \mathrm{mg} / \mathrm{dL}, 8.8 \pm 1.83 \%$, $9.37 \pm 5.96 \quad$ years, $138,44 \pm 14,13 / 84,44 \pm 19,25$ $\mathrm{mmHg}, 30.32 \pm 3.2 \mathrm{mg} / \mathrm{day}$ and $1.33 \pm 0.64 \mathrm{mg} / \mathrm{dl}$. The details data presented in Table 1.

The univariate analysis marked that the microalbuminuria development group had longer diabetes duration (8.24 vs. 5.24 years) comparing to the normoalbuminuria group. Furthermore, this group also received more insulin therapy $(66.67 \%$ vs. $33.33 \%)$, has a poorer glycemic control (8.71\% vs. $6.67 \%)$, and higher baseline of UACR $(17.45 \mathrm{mg} / \mathrm{g}$ vs. $10.65 \mathrm{mg} / \mathrm{g}$ ) (it can be seen in Table 1). Though more hypertension subjects were included $(44.1 \%$ vs. $34.4 \%)$ in the microalbuminuria development group $(p=0.053)$, the average blood pressure levels were quite identical between both groups. From this study, it is attained a total of 25 subjects that had hypertension. Moreover, the mean of systolic/diastolic blood pressure was $132 / 78 \mathrm{mmHg}$ after treatment. $80 \%$ $(20 / 25)$ of the hypertension subjects was treated with ACEIs or ARBs.

In scrutinizing the significant risk factors reported in the univariate analysis or in previous studies, this study applied binary logistic regression. It is attained that a higher baseline of UACR (OR 1.19, 95\% Cl 1.12-1.25, p<0.001) and $\mathrm{HbA1c}$ (OR 1.39, 95\% Cl 1.04-1.81, $\mathrm{p}=0.023$ ) levels were the two independent risk factors in microalbuminuria development (Table 2). The cutoff point chosen for UACR and $\mathrm{HbA} 1 \mathrm{c}$ were $10 \mathrm{mg} / \mathrm{g}$ (sensitivity, $80.9 \%$; specificity, $63.6 \% ; \mathrm{AUC}=0.774, \mathrm{Cl}=0.72-0.83$ ) and $8.0 \%$ (sensitivity, 72.1\%; specificity, 61.6\%; $\mathrm{AUC}=0.698, \mathrm{Cl}=0.63-0.77$ ), it is obtained by using the ROC curve analysis and Youden index.

Therefore, we interpreted the baseline UACR of 10 $29.9 \mathrm{mg} / \mathrm{g}$ as high-normal, and $<10 \mathrm{mg} / \mathrm{g}$ as low-normal albuminuria. The analysis was normalized with respect to low-normal UACR $(<10 \mathrm{mg} / \mathrm{g})$ and $\mathrm{HbA} 1 \mathrm{c}<8 \%$ when considering the risk of microalbuminuria in subjects. The conformed hazard ratio (HR) for subjects with low-normal UACR/HbA1c $>8 \%$, high-normal UACR/HbA1c $<8 \%$ and high-normal UACR/ HbA1c>8\% were 2.59 ( $p=0.108), 6.16$ ( $p 1 / 40.001)$, and $16.69(p<0.001)$, seriatim. The impact of $\mathrm{HbA} 1 \mathrm{c}>8 \%$ was not statistically significant for microalbuminuria development in patients with low-normal UACR. However, a HbA1c level of $>8.0 \%$ corresponds significantly with the risk of microalbuminuria development among patients with high-normal baseline albuminuria (adjusted HR $=2.89 ; p=0.002$, data not shown). In gauging the impact of glycemic control, subjects in both of the low-normal and high-normal UACR subgroups were investigated by stratifying the $\mathrm{HbA1c}$ levels into four subgroups, which is; $<8 \%, 8-9 \%, 9-10 \%$, and $>10 \%$ (Table 3).

Table 1. Demographic data of 70 type 2 diabetic patients

\begin{tabular}{|c|c|c|c|c|}
\hline & Overall $(\mathrm{N}=70)$ & Normoalbuminuria $(\mathrm{N}=25)$ & Microalbuminuria $(\mathrm{N}=45)$ & $P$ \\
\hline & Mean $\pm S D$ & Mean $\pm S D$ & Mean $\pm S D$ & $P$ \\
\hline Age (year) & $51.89 \pm 6.78$ & $52.88 \pm 4.56$ & $55.67 \pm 5.76$ & 0.57 \\
\hline Diabetes duration (year) & $9.37 \pm 5.96$ & $5.24 \pm 2.12$ & $8.24 \pm 3.76$ & $0.01^{*}$ \\
\hline BMI & $25.49 \pm 3.45$ & $25.12 \pm 3.24$ & $25.55 \pm 2.78$ & 0.52 \\
\hline Hyperthension $(\mathrm{mmHg})$ & $25(35.7 \%)$ & $20(80 \%)$ & $5(20 \%)$ & \\
\hline Systolic BP & $138.44 \pm 14.13$ & $118.34 \pm 2.45$ & $132.13 \pm 2.12$ & 0.05 \\
\hline Diastolic BP & $84.44 \pm 19.25$ & $88.12 \pm 2.37$ & $88.14 \pm 3.18$ & 0.06 \\
\hline Retinopathy & $13(18.57 \%$ & $3(23.07 \%)$ & $10(76.93 \%)$ & 0.07 \\
\hline \multicolumn{5}{|l|}{ Baseline Laboratory } \\
\hline HbA1c level (\%) & $8.8 \pm 1.8$ & $6.67 \pm 76$ & $8.71 \pm 23$ & $<0.01^{*}$ \\
\hline FBS $(\mathrm{mg} / \mathrm{dL})$ & $182.51 \pm 74.63$ & $180.43 \pm 86.12$ & $183.23 \pm 17$ & 0.08 \\
\hline PPBS $(\mathrm{mg} / \mathrm{dL})$ & $186.25 \pm 26.72$ & $184.59 \pm 22.34$ & $191 \pm 22.18$ & 0.24 \\
\hline Urinary creatinin $(\mathrm{mg} / \mathrm{dL})$ & $1.33 \pm 0.64$ & $1.32 \pm 0.54$ & $1.33 \pm 0.87$ & 0.43 \\
\hline UACR & $12.61 \pm 2.4$ & $10.65 \pm 3.2$ & $17.45 \pm 5.76$ & $<0.01^{*}$ \\
\hline \multicolumn{5}{|l|}{ Medication } \\
\hline OADs & $62(88.57 \%)$ & $53(85.48 \%)$ & $9(14.52 \%)$ & 0.90 \\
\hline Insulin & $12(17.14 \%)$ & $8(66.67 \%)$ & $4(33.33 \%)$ & $<0.01^{*}$ \\
\hline ACEI/ARB & $25((35.71 \%)$ & $20(80 \%)$ & $5(20 \%)$ & 0.11 \\
\hline
\end{tabular}

Annotation: a Mann-Whitney U-test for continuous variables and chi square test for nominal variables. ${ }^{*} p$ value $<0.05$ 
Table 2. Blood Glucose Difference Between Treatment Groups

\begin{tabular}{|l|l|l|l|}
\hline & OR & $95 \% \mathrm{Cl}$ & $p$ Value \\
\hline Diabetes duration & 1.03 & $0.97-1.07$ & 0.67 \\
\hline Hyperthension & 1.63 & $0.43-6.15$ & 0.44 \\
\hline Insulin & 2.52 & $0.97-6.08$ & 0.06 \\
\hline HbA1c & 1.39 & $1.04-1.81$ & 0.02 \\
\hline UACR & 1.19 & $1.12-1.25$ & $<0.01$ \\
\hline
\end{tabular}

Annotation: ${ }^{*}$ Significant; ${ }^{t}$ Paired $t ;{ }^{y}$ One Way ANOVA

Table 3. Cox Regression annual incidence rate of microalbuminuria in various UACR and HbA1c level subgroups

\begin{tabular}{|c|c|c|c|c|c|c|}
\hline \multirow{2}{*}{ UACR } & \multirow{2}{*}{$\mathrm{HbA1c}$} & \multicolumn{2}{|l|}{ Unadjusted } & \multicolumn{2}{|l|}{ Adjusted } & \multirow[t]{2}{*}{ Annual Incidence(\%) } \\
\hline & & $\mathrm{HR}^{*}(95 \% \mathrm{Cl})$ & $p$ & $\mathrm{HR}^{*}(95 \% \mathrm{Cl})$ & $\mathrm{P}$ & \\
\hline \multirow[t]{4}{*}{$<10$} & $<8$ & 1 & & 1 & & 0.42 \\
\hline & $8-9$ & $1.80(0.42-7.56)$ & 0.42 & $1.83(0.42-8.01)$ & 0.43 & 0.78 \\
\hline & $9-10$ & $4.80(0.93-25.15)$ & 0.06 & $3.89(0.58-25.87)$ & 0.16 & 1.62 \\
\hline & $>10$ & $6.02(1.78-9.15)$ & 0.02 & $3.59(0.54-23.86)$ & 0.19 & 3.38 \\
\hline \multirow[t]{4}{*}{$10-29.9$} & $<8$ & 1 & & 1 & & 2.34 \\
\hline & 8-9 & $2.18(1.08-4.35)$ & 0.03 & $2,79(1.29-6.03)$ & 0.01 & 4.82 \\
\hline & $9-10$ & $2.44(1.17-5.28)$ & 0.02 & $2.84(1.22-6.53)$ & 0.01 & 5.02 \\
\hline & $>10$ & $4.05(1.78-9.15)$ & 0.01 & $3.63(1.26-10.48)$ & 0.02 & 8.16 \\
\hline
\end{tabular}

\section{DISCUSSION}

There was no unanimity among the microalbuminuria influencing factors shown in previous studies; however, a higher normal baseline albuminuria and glucose levels were noticed to be the most common factors that correlated with microalbuminuria development in diabetic patients ${ }^{12,13}$ In this study, interrelationships between these two factors that were not previously shown is detected. High-normal albuminuria level has a significant impact on microalbuminuria development amid patients with any baseline levels of $\mathrm{HbA1c}$. Furthermore, glycemic control has a higher impact on subjects that already have a highnormal baseline albuminuria. Moreover, this glycemic control effect was not investigated in patients with lownormal albuminuria.

Normal albuminuria traditional definition was outlined by UACR below $30 \mathrm{mg} / \mathrm{g}$ or UAER below $20 \mathrm{mg} / \mathrm{min}$. This range was specified according to $95 \%$ of upper bound range of "normal" individuals. ${ }^{14}$ Some studies have presented that diabetes patients with higher levels of normal albuminuria have higher risks of cardiovascular events. ${ }^{15}$ In line with that, it is presented by American Diabetic Association (ADA) that a high-normal albuminuria is the strongest predictor for the onset of microalbuminuria in patients with type 2 diabetes. $^{3}$ Nevertheless, there was no consensus amid the studies for a clearly defined optimal threshold of "high-normal" albuminuria in single out microalbuminuria development. ${ }^{15,16}$ Medical consideration should be performed for patients with higher normal albuminuria to preclude its ongoing kidney deterioration. Glycemic control carried out a vital role in diabetic microvascular complications. It was presented that for each $1 \%$ reduction in updated mean of $\mathrm{HbA} 1 \mathrm{c}$ was correlated with a $37 \%$ reduction in microvascular complication risks. Intensive glycemic control was considered as ineffective in preventing cardiovascular complications in patients with high cardiovascular risks. Nonetheless, certain benefits on prevention of diabetic nephropathy, like the intensive glycemic control can still be obtained by patients with high cardiovascular risks. ${ }^{17,18}$ The execution of glycemic control may have different benefits in different stages of diabetic nephropathy. There was no randomized control trial attesting that intensive glycemic control can be beneficial especially in slowing diabetic nephropathy progression during the late stages of diabetic nephropathy (macroalbuminuria stage or CKD stage 3-5) amid the type 2 diabetes patients. ${ }^{19}$ The United Kingdom Prospective Diabetes Study (UKPDS) study10 had presented that glycemic control can have a significant $24 \%$ risk reduction, when applied as the primary microalbuminuria prevention method for patients with normoalbuminuria. Regardless, there were studies that did not disclose glucose control as a good indicator for estimating microalbuminuria development ${ }^{20}$. Therefore, we believe that the interrelationships among the different factors may act on their prediction power. In this study, we figured out the baseline UACR as a strong predictor in determining microalbuminuria. The baseline UACR had demonstrated high impacts on subjects with both low and high $\mathrm{HbA1c}$ baseline levels. The HbA1c level indicated impact on patients with high-normal baseline UACR but the HbA1c level had shown no significance for patients with lownormal albuminuria. It is difficult to explain why subjects with high-normal UACR were more susceptible to glycemic insults than those in low-normal UACR. Further studies are demanded to investigate the pathophysiological mechanism. This study was bounded by its retrospective entity and certain missing data such as smoking.

\section{CONCLUSION}

In conclusion, we had presented that both the baseline UACR and the glycohemoglobin levels are indicators for microalbuminuria development in type 2 diabetes patients. Glycemic control is take an important role in slowing microalbuminuria progression among patients with highnormal UACR.

Acknowledgements: This research was financed by PROLANIS Program, a program by Primary Health Care and Medical Faculty of Jenderal Soedirman University, Indonesia.

\section{REFERENCES}

1. Edwina, DA., Manaf, A., Efrida. Pola Komplikasi Kronis Penderita Diabetes Melitus Tipe 2 Rawat Inap di Bagian Penyakit Dalam RS. Dr. M. Djamil Padang Januari 2011Desember 2012. Jurnal Kedokteran Andalas. 2015; 4(1): 102-106 
2. Hendromartono. "Nefropati Diabetik". IImu Penyakit Dalam. Jakarta: Interna Publishing, 2015.

3. American Diabetes Association. Standards of Medical Care in Diabetes. Diabetes Care. 2018; 40 (Suppl 1): S11-S24.

4. International Diabetes Federation (IDF). IDF Diabetes Atlas eight edition. Jurnal Online. 2017. Diunduh 28 Februari 2018. Tersedia dari: www. diabetesatlas.org.

5. Kementerian Kesehatan Republik Indonesia. Hasil Utama Riskesdas 2018. Jakarta :Kementerian Kesehatan Republik Indonesia. 2018

6. Lee, E.S., Tang, W.E. The Prevalence of Albuminuria among Diabetic Patients in A Primary Care Setting in Singapore. Singapore Med J. 2015; 56(12) : 681-686.

7. Miller, W.G., Bruns, D.E., Hortin, G.L., Sanberg, S., Aakre, M., McQueen, M.J., et al. Current Issues in Measurement and Reporting of Urinary Albumin Excretion. Clin Chem. 2009; 55(1) : 24-38.

8. Idowu, A.A., Ajose, A.O., Adedeji, A.T., Adegoke, A.O., Jimoh, K.A. Microalbuminuria, Other Markers of Nephropathy and Biochemical Derangements in Type 2 Diabetes Mellitus : Relationships and Determinants. Ghana Med J. 2017; 51(2) : 56-63.

9. Heerspink, H.J., Gansevoort, R.T., Brenner B.M., Cooper, M.E., Parving, H.H., Shahinfar, S., et al. Comparison of Different Measures of Urinary Protein Excretion for Prediction of Renal Events. J Am Soc Nephrol. 2010; 21(8) : 1355-1360.

10. Charisma, A.M. Korelasi Kadar Rata-Rata Glukosa Darah Puasa dan 2 Jam Post Prondial Tiga Bulan Terakhir dengan Nilai HbA1c padaPasien Diabetes Mellitus Prolanis BPJS Kabupaten Kediri Periode Mei-Agustus 2017. J Kesehatan Masyarakat Indonesia. 2017; 12(2):1-11.

11. Aveonita.,Agtha R. Effect Of Aloe Vera In Lowering Blood Glucose Levels on Diabetes Melitus.Journal MAJORITY. 2015; 4(2): 102-109.
12. Hamed B. S, Pavcovic. P, Metelco. Z. Review, Microalbuminuria and Diabetes Melitus. DiabetologiCroatica. 2012; 31-4.

13. Purdil K, Momin K, Aziz A, Abdul A, Wasil K. Relationship of Glycemic Kontrol With Prevalence of Microalbuminuri in Diabetic Patients, Gomal J Med Sci. 2012; 10: 201-4

14. Bhoomika P. D, Amit H.A. Gauravi A.D. 2012. Study of Microalbuminuria in Diabetes Type 2 Patients as a marker of morbidity (A Study of 100 cases in Rajkot City) Department of Pathology; P. D. U. Medical College, Rajkot, Gujarat, India;18:208-213.

15. International Diabetes Federation (IDF). 2017. IDF Diabetes Atlas eight edition. Jurnal Online. Diunduh 28 Februari 2018. Tersediadari: www.diabetesatlas.org.

16. Philip, M.F., Cherney, D., Gilbert, R.E., Senior, P. Clinical Practice Guidelines : Chronic Kidney Disease in Diabetes. Can J Diabetes. 2018; 42(2018) : S201-S209.

17. Farmer, A. Use Of HbA1c InThe Diagnosis Of Diabetes.British Medical Jurnal. 2012; 235:1-2.

18. Gupta, Mayank. Singh, Jagat P. Correlation Of Microalbuminuria With Glycosylated Haemoglobin In Patients Of Diabetes Having Nephropathy. International Journal of advances in medicine. 2017; 4(3):805-808.

19. National Kidney Foundation-Kidney Disease Outcome Quality Initiative (NKF-KDOQI). 2002. KDOQI Clinical Practice Guideliner for Chronic Kidney Disease: Evaluation, Classification, and Stratification.

20. Naveen. P, Kannan. N , Vamseedhar A , Bhanu P. G , Aravind K. R. Evaluation of Glycated hemoglobin and Microalbuminuria as early risk markers of Nephropathy in Type 2 Diabetes melitus, Int J Biol Med Res. 2012; 3(2): 1724- 1726 